\title{
Risk factors and molecular mechanisms of esophageal cancer: differences between the histologic subtypes
}

\author{
Masayuki Watanabe \\ Department of Gastroenterological Surgery, Esophageal Cancer Division, Cancer Institute Hospital of Japanese Foundation for Cancer Research, \\ Tokyo 1358550, Japan.
}

Correspondence to: Dr. Masayuki Watanabe, Department of Gastroenterological Surgery, Esophageal Cancer Division, Cancer Institute Hospital of Japanese Foundation for Cancer Research, 3-8-31 Ariake, Koto-ku, Tokyo 1358550, Japan. E-mail: masayuki.watanabe@jfcr.or.jp

\section{A B S T R A C T}

The two major histologic subtypes of esophageal cancer have different risk factors as well as different molecular mechanisms. In this review, the differences in risk factors and genetic/epigenetic alterations between esophageal squamous cell carcinoma (ESCC) and esophageal adenocarcinoma (EAC) will be discussed. Cigarette smoking and alcohol consumption are risk factors for ESCC, while gastroesophageal reflux, cigarette smoking, and obesity are the main EAC risk factors. Commonly mutated genes of both subtypes are TP53 and PIK3CA. Recent genome-wide analysis revealed that the activation of the RAC1 pathway may contribute to EAC tumorigenesis. Clustered abnormality in copy number was observed in several genes in ESCC, whereas a few genes were specifically altered at high frequency in EAC. Epigenetic changes, such as DNA methylation, histone modifications, and altered expression of microRNAs, have been revealed to influence carcinogenesis and progression of both ESCC and EAC.

Key words: Epigenetic alterations, esophageal cancer, genetic alterations, risk factors

\section{Introduction}

Esophageal cancer affects more than 450,000 people every year worldwide ${ }^{[1]}$ and is the 6th leading cause of cancer-related mortality. ${ }^{[2]}$ The two major histologic subtypes of esophageal cancer are esophageal squamous cell carcinoma (ESCC) and esophageal adenocarcinoma (EAC). ESCCs are by far more common in South East and Central Asia (79\% of the total global ESCC cases), while the highest number of EAC is found in Northern and Western Europe, North America and Oceania (46\% of the total global AC cases) ${ }^{[3]}$ The remarkable variations in geographic distribution indicate that different environmental risk factors likely affect the occurrence of esophageal cancer.

Recent progress in molecular biology has revealed that several genetic and epigenetic alterations are implicated in both carcinogenesis and progression of esophageal cancer. Genetic alterations include a chromosomal loss or gain, loss of heterozygosity (LOH), and amplification or mutations of genes. Epigenetic changes, such as DNA methylation, histone modifications, and altered expression of microRNAs regulate gene expression through mechanisms other than changes in DNA

\section{Access this article online}

Quick Response Code:

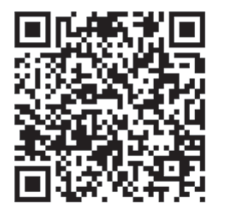

Website:

www.jcmtjournal.com

DOI:

10.4103/2394-4722.153534 sequence. It has become evident that molecular mechanisms also differ greatly between the two histologic subtypes.

In this review, the differences in both risk factors and molecular mechanisms between ESCC and EAC will be summarized.

\section{Risk Factors}

There are different risk factors between ESCC and EAC. Demonstrated in Table 1 are the major risk factors for each histologic subtype.

Both cigarette smoking and alcohol consumption are well-established risk factors for ESCC, ${ }^{[4,5]}$ with the risk in heavy smokers/drinkers being 50 times greater than those who neither drank nor smoked. ${ }^{\left[{ }^{6}\right]}$ Recently, deficiency in the enzyme aldehyde dehydrogenase 2 (ALDH2), which causes so-called alcohol flushing response, has been revealed to increase the risk of alcohol-related ESCC. ${ }^{[7]}$ In East Asian populations, there is a variant of ALDH2, resulting from the replacement of glutamate at position 487 with lysine, with the lysine allele encoding an inactive protein. ${ }^{\left[{ }^{[8]}\right.}$ Drinking hot beverages may also increase the risk of ESCC. ${ }^{[9]}$ In addition, patients with achalasia are at markedly increased risk of developing ESCC ${ }^{[10]}$ while both ESCC and EAC may develop as a late complication of caustic injury. ${ }^{[1]}$ Oncogenic human papillomaviruses may increase the risk of ESCC, but the evidence is inconclusive. ${ }^{[12]}$

Gastroesophageal reflux disease (GERD), cigarette smoking, and obesity are the main EAC risk factors. ${ }^{[13]}$ At least weekly symptoms of GERD increases the odds 
of EAC five-fold, while daily symptoms increased the odds seven-fold, when compared with those with less frequent episodes. ${ }^{[14]}$ The relative risk of esophageal and gastric cardia $\mathrm{AC}$ was 2.32 for current smokers and 1.62 for ex-smokers, as compared with never-smokers. ${ }^{[15]}$ However, a meta-analysis provided definite evidence of an absence of association between alcohol drinking and esophageal and gastric cardia AC risk. ${ }^{[16]}$ A systematic review and meta-analysis revealed a high body mass index (BMI) to be associated with a summary odds ratio for gastroesophageal AC of 1.5. ${ }^{[17]}$ A recent prospective cohort study in the United States found that a BMI $\geq 35$ was associated with a hazard ratio of 3.67 compared with those with a normal-range BMI. ${ }^{[18]}$ Obesity may predispose to reflux through mechanical means, while adipokines and cytokines secreted from adipocytes and inflammatory cells are known to influence tumor development. ${ }^{[19]}$ Helicobacter pylori infection has been reported to actually decrease the risk of EAC by $41 \%{ }^{[20]}$ through gastric atrophy, which leads to acid reduction.

Radiotherapy for thoracic diseases, such as breast cancer and Hodgkin's lymphoma, increases the risk of both ESCC and EAC. ${ }^{[21,22]}$ The incidence of both ESCC and EAC increases with age. There is a strong male predominance with up to eight men/one woman for EAC and three men/one woman for ESCC. ${ }^{[23,24]}$ Fat distribution in obese men is predominantly abdominal, and increasing abdominal diameter has been associated with an increased EAC risk. ${ }^{[25]}$ However, the male predominance of ESCC can be explained by the prevalence of smoking and alcohol drinking among males. ${ }^{[26]}$ Although an inhibitory effect of estrogen in the growth of esophageal cancer cells has been reported, there is no firm conclusion on the role of estrogen in human esophageal cancer etiology. ${ }^{[27]}$ The familial form of ESCC is rare, although familial aggregation has been reported in a high incidence area in China. ${ }^{[28]}$ In contrast, familial clustering of Barrett's esophagus and EAC has been observed. In a European cohort study, $7 \%$ of cases of Barrett's esophagus and EAC were familial. ${ }^{[29]}$

The efficacy of endoscopic surveillance for high-risk individuals is controversial. Both lugol chromoendoscopy and an innovative optical image-enhanced technology such as the narrow band imaging have been reported to be useful in detecting early ESCC. ${ }^{[30,31]}$ In addition, endoscopic esophageal surveillance has been recommended for newly-diagnosed head and neck cancer patients. ${ }^{[32]}$ However, there is no study evaluating the efficacy of endoscopic surveillance or screening among people heavily exposed to ESCC risk factors. In contrast, endoscopic screening is recommended for patients with multiple risk factors in Barrett's esophagus, although there is no randomized clinical trial that has shown efficacy in preventing deaths due to esophageal cancer. ${ }^{[33]}$ For patients with Barrett's esophagus without dysplasia, endoscopic surveillance at intervals of
3-5 years has been recommended, and endoscopic eradication therapy is the treatment of choice for those with high-grade dysplasia (HGD). ${ }^{[33]}$ Recently, however, lengthening surveillance or discontinuing surveillance of patients with persistent non-dysplastic Barrett's esophagus (NDBE) has been discussed because of an annual cancer incidence of only $0.1-0.3 \%$ in such patients. ${ }^{[34]}$

\section{Molecular Mechanisms}

\section{Mutations}

Recently, the results of whole-exome or whole-genome sequencing to identify somatic mutations in $\mathrm{ESCC}^{[35]}$ and $\mathrm{EAC}^{[36]}$ have been reported. The frequently mutated genes in esophageal cancers are shown in Table 2 . The commonly mutated genes of both subtypes are TP53 and PIK3CA. TP53 is a major tumor-suppressor gene, its primary function being maintenance of genetic stability and DNA repair capacity. ${ }^{[37]}$ PIK3CA is a kinase activator of the phosphoinositide 3-kinase $(\mathrm{PI} 3 \mathrm{~K}) / \mathrm{AKT}$ pathway and is frequently mutated in many types of human cancers, ${ }^{[38]}$ including ESCC. ${ }^{[39]}$ NOTCH1, FAT1, FAT2, KMT2D and ZNF750 are also significantly mutated in ESCC. NOTCH1 encodes one of the notch family receptors, and the notch signaling is a key pathway of the stem cell signaling network. ${ }^{[40]}$ There are other recently identified mutated genes ${ }^{[35]}$ and the much about the functions remains to be researched.

Table 1: Risk factors of esophageal cancer

\begin{tabular}{ll}
\hline Squamous cell carcinoma & Adenocarcinoma \\
\hline Cigarette smoking & Gastro-esophageal reflux disease \\
Alcohol drinking & Barrett's esophagus \\
ALDH2 deficiency & Reflux symptoms \\
Drinking very hot liquids & Obesity \\
Achalasia & Cigarette smoking \\
Caustic injury & $\begin{array}{l}\text { Diet (high in processed meat, } \\
\text { low in fruits, vegetables) }\end{array}$ \\
History of thoracic radiation & History of thoracic radiation \\
Tylosis & Anticholinergic agents \\
Human papilloma virus & Family history \\
infection & Helicobacter pylori infection \\
N-nitrosamines & (decreased risk)
\end{tabular}

Table 2: Representative mutated genes in esophageal cancer

\begin{tabular}{ll}
\hline Squamous cell carcinoma & Adenocarcinoma \\
\hline TP53 & TP53 \\
KMT2D & CDKN2A \\
FAT1 & SMAD4 \\
FAT2 & ARID1A \\
NOTCH1 & PIK3CA \\
ZNF750 & SPG20 \\
PIK3CA & TLR4 \\
& ELMO1 \\
& DOCK2 \\
\hline
\end{tabular}

Bold: Genes commonly mutated in both subtypes 
CDKN2A, SMAD4, ARID1A, SPG20, TLR4, ELMO1 and $D O C K 2$ are significantly mutated in EAC. p16 ${ }^{\mathrm{INK} 4 \mathrm{a}}$, encoded by $C D K N 2 A$, inhibits CDK4 and 6 that bind to cyclin D1 and blocks abnormal cell growth and proliferation. ${ }^{[41]}$ SMAD4 is a key intracellular mediator of transforming growth factor-beta signaling and is known to act as a tumor suppressor. ${ }^{[42]} A R I D 1 A$, which is one of the chromatin remodeling genes, is frequently mutated in a variety of human cancers. ${ }^{[43]}$ Among the remaining four newly identified genes, ELMO1 and DOCK2 are upstream modulators of RAC1 GTPase, suggesting the potential activation of the RAC1 pathway as a contributor to EAC tumorigenesis. ${ }^{[36]}$

Recently, comparison of mutated genes among NDBE, HGD, and EAC revealed the majority of recurrently mutated genes in EAC, except TP53 and SMAD4, were also mutated in NDBE. ${ }^{[44]}$ Mutations of TP53 and SMAD4 were stage-specific, confined to HGD and EAC, respectively. ${ }^{[44]}$

\section{DNA copy number alterations}

Clustered abnormality in copy number was observed in several genes in ESCC [Table 3], whereas a few genes were specifically altered at high frequency in EAC. ${ }^{[45]}$ Instead, EAC samples demonstrated more widespread genomic instability and the total DNA copy number alterations were an independent prognostic factor. ${ }^{[45]}$

Amplification and $\mathrm{LOH}$ observed in ESCC are summarized in Table 3. Amplification and overexpression of $C C N D 1$, which positively regulates G1/S transition, are frequently observed. ${ }^{[46]}$ The $\mathrm{PI} 3 \mathrm{~K} / \mathrm{AKT}$ pathway is activated by amplification and overexpression of receptor tyrosine kinases (fibroblast growth factor receptor 1 and epidermal growth factor receptor), KRAS, and $P I K 3 C A .{ }^{[35]}$ The transcriptional genes $M Y C$ and $S O X 2$ are occasionally amplified. Deletion of several tumor suppressor genes, including TP53, adenomatous polyposis coli (APC), CDKN2A, and FHIT, is observed in ESCC. APC suppresses canonical Wnt signaling through inhibition of $\beta$-catenin, while it plays roles in several other fundamental cellular processes such as cell adhesion, migration, and chromosome segregation. ${ }^{[47]}$ Loss of FHIT transcripts affects development and progression of various types of cancers. ${ }^{[48]}$ Loss of FHIT expression was reported to be associated with exposure to environmental carcinogens. $^{[49,50]}$

Amplification/overexpression of ERBB2 (also known as human epidermal growth-factor receptor 2/neu) gene has been observed in $24-32 \%$ of esophagogastric junction $\mathrm{AC} .^{[51]}$ The positive rate in EAC has been reported to be higher than that observed in gastric cancer. ${ }^{[51]}$ Trastuzumab, an antibody to ERBB2, added to chemotherapy, improved survival in patients with HER-2 positive advanced gastric or gastroesophageal junction AC compared with chemotherapy alone. ${ }^{[52]}$
Comparison of cancer-associated genetic abnormalities in the columnar-lined esophagus, with and without goblet cells, has revealed frequent copy number abnormalities in intestinal metaplasia, whereas no such changes were observed in nongoblet cell metaplasia. ${ }^{[53]}$

\section{Epigenetic alterations}

The promoter hypermethylation of several tumor suppressor genes, such as $A P C, C D K N 2 A, C D H 1, F H I T$, RARB, Ras-association domain family 1 (RASSF1), MGMT, MLH1, and MSH2, causes decreased expression of these genes and has been known to affect carcinogenesis of ESCC ${ }^{[54]}$ [Table 4]. E-cadherin, encoded by $C D H 1$, is a calcium-dependent adhesion molecule that plays a crucial role in the maintenance of intercellular junctions in normal epithelial cells. ${ }^{[55]}$ The $R A R B$ gene encodes retinoic acid receptor beta, a central regulator to normal growth and differentiation of a variety of epithelial cells. ${ }^{[56]}$ The RASSF1 encodes a protein similar to RAS effector proteins. RASSF1A protein modulates a broad range of cellular functions essential for normal growth control. ${ }^{[57]}$ The $M G M T$ gene encodes $\mathrm{O}^{6}$-methyl-guanine-DNA methyltransferase, a DNA repair

Table 3: Representative amplified or deleted genes in squamous cell carcinoma of the esophagus

\begin{tabular}{|c|c|c|}
\hline Genes & Location & Function \\
\hline \multicolumn{3}{|c|}{ Amplification } \\
\hline$C C N D 1$ & $11 \mathrm{q} 13$ & Cell cycle progression \\
\hline FGFR1 & 8 p11 & Mitogenesis, differentiation \\
\hline$E G F R$ & $7 \mathrm{p} 12$ & Proliferation \\
\hline PIK3CA & $3 q 26$ & Cell growth, survival, proliferation \\
\hline$M Y C$ & $8 \mathrm{q} 24$ & $\begin{array}{l}\text { Cell cycle progression, } \\
\text { transformation }\end{array}$ \\
\hline SOX2 & $3 q 26$ & Stemness \\
\hline$K R A S$ & $12 \mathrm{p} 12$ & Proliferation \\
\hline \multicolumn{3}{|c|}{$\begin{array}{l}\text { Loss of } \\
\text { heterozygosity }\end{array}$} \\
\hline TP53 & $17 q 13$ & $\begin{array}{l}\text { Cell cycle arrest, DNA repair, } \\
\text { apoptosis }\end{array}$ \\
\hline$A P C$ & $5 \mathrm{q} 21$ & Antagonist of Wnt signaling pathway \\
\hline$C D K N 2 A$ & $9 \mathrm{p} 21$ & Cell cycle arrest \\
\hline FHIT & $3 p 14$ & Purine metabolism \\
\hline
\end{tabular}

Table 4: Representative hypermethylated genes in esophageal cancer

\begin{tabular}{|c|c|}
\hline Squamous cell carcinoma & Adenocarcinoma \\
\hline$\overline{A P C}$ & $A P C$ \\
\hline$C D K N 2 A$ & TIMP3 \\
\hline CDH1 & $C D K N 2 A$ \\
\hline FHIT & $C D H 1$ \\
\hline$R A R B$ & $M G M T$ \\
\hline RASSF1 & $D A P K$ \\
\hline$M G M T$ & FHIT \\
\hline$M L H 1$ & $A K A P 12$ \\
\hline MSH2 & SOCS-3 \\
\hline
\end{tabular}

Bold: Genes commonly hypermethylated in both subtypes 
enzyme, which removes methyl- or alkyl-groups from guanidine after chemical modulation, therefore protecting cells from $\mathrm{G}$ to A mutations. ${ }^{[58]} \mathrm{MLH1}$ and $\mathrm{MSH} 2$ are two key DNA mismatch repair genes and epigenetic silencing of these genes may lead to microsatellite instability. ${ }^{[59]}$

Promotors of $A P C$, tissue inhibitor of metalloproteinases 3 (TIMP3), ${ }^{[60]}$ CDKN2A, CDH1, MGMT, DAPK, FHIT, ${ }^{[61]} A K A P 12,{ }^{[62]}$ and suppressors of cytokine signaling $(S O C S)^{[63]}$ have been reported to be frequently hypermethylated in EAC [Table 4]. TIMP3 belongs to a family of genes that inhibit matrix metalloproteinases, a group of peptides involved in degeneration of extracellular matrix. ${ }^{[64]}$ Death-associated protein kinase 1 is a positive mediator of gamma-interferon-induced programmed cell death. ${ }^{[65]}$ A-kinase anchoring protein 12 is a multivalent anchoring protein and an important regulator of the beta2-adrenergic receptor complex. ${ }^{[62]}$ SOCS proteins act as negative regulators of JAK/STAT pathways and may represent tumor suppressors. ${ }^{[66]}$ Promotor methylation and subsequent transcript down-regulation of SOCS-3 and to a much lesser extent, SOCS-1 were involved in the multistep carcinogenesis of Barrett's AC. ${ }^{[63]}$

Genome-wide DNA hypomethylation may also contribute to tumorigenesis. Long interspersed element 1 (LINE-1) is a retrotransposon comprising about $17 \%$ of the human genome, and the levels of LINE-1 methylation can be a surrogate marker of genome-wide DNA methylation. ${ }^{[54]}$ Hypomethylation levels of LINE-1 are frequently observed in ESCC and correlate with a poor prognosis. ${ }^{[67]}$ On the other hand, genome-wide methylation analysis also revealed that overall methylation of $\mathrm{CpG}$ islands was higher, but outside of $\mathrm{CpG}$ islands was lower, in Barrett's esophagus and EAC tissues than in normal esophageal tissues. ${ }^{[68]}$

Histone modifications, including acetylation, methylation, phosphorylation, and ubiquitination, regulate gene expression and are implicated in carcinogenesis. Levels of acetylation/deacetylation of histone proteins are determined by two opposing groups of enzymes, histone acetyltransferases, and histone deacetylases (HDACs). ${ }^{69]}$ HDAC inhibitors have demonstrated antitumor effects in various cancers. ${ }^{[70]}$ Of interest, high HDAC2 expression has been associated with aggressive EAC behavior. ${ }^{[71]}$

MicroRNAs (miRs), small, noncoding RNA molecules consisting of 19-25 nucleotides, also regulate gene expression epigenetically. ${ }^{[72]}$ MicroRNAs can act as tumor promoters (onco-miR) through targeting expression of tumor suppressor genes or as tumor suppressors (ts-miR) through targeting expression of oncogenes. miR-21 functions as an onco-miR because it is overexpressed in many types of cancers, including ESCC $^{[73,74]}$ and EAC. ${ }^{[75]}$ Targets of miR-21 have been shown to be PDCD4 (programmed cell death 4) ${ }^{[73]}$ and phosphatase and tensin homolog. ${ }^{[76]}$ Serum or serum exosomal miR-21 has been reported to be a biomarker in ESCC. ${ }^{[77,78]}$ miR-375 is considered as ts-miR in several cancers, including both histologic subtypes of esophageal cancer. $^{[79,80]}$ Reduced levels of miR-375 in cancerous tissue of EAC patients with Barrett's were strongly associated with a worse prognosis. ${ }^{[80]}$ miR-205 was down-regulated in both ESCC and EAC. ${ }^{[81,82]}$ Knockdown of miR-205 expression enhanced expression of zinc finger E-box homeobox 2, accompanied by a reduction of E-cadherin, leading to epithelial-mesenchymal transition. ${ }^{[82]}$ miR-223 expression was significantly higher in ESCC with an inverse relationship with F-box and WD repeat domain-containing 7 , a cell cycle regulatory gene whose protein product ubiquitinates cell cycle regulators such as c-Myc, cyclin E and c-jun. ${ }^{[83]}$

Recently, changes in expression of several miRs have been reported in Barrett's esophagus. ${ }^{[84]}$ miR expressions were compared between 2 groups of patients with Barrett's esophagus who either developed or did not develop EAC over a course of 5 years. ${ }^{[85]}$ As a result, 4 miRs (miR-192, miR-194, miR-196a, and miR-196b) were found to show significantly higher expression in patients with progression to EAC than in those without.

\section{Conclusion}

In this review, the risk factors and molecular mechanisms of esophageal cancer, with special reference to the differences between two histologic subtypes, have been discussed. In spite of advances in the diagnostic tools and therapeutic strategies, esophageal cancer still remains one of the most lethal malignancies. In order to improve outcomes, early detection of tumors based on knowledge of risk factors is needed. In addition, efforts to identify novel therapeutic targets through molecular biological techniques are essential.

\section{References}

1 Pennathur A, Gibson MK, Jobe BA, Luketich JD. Oesophageal carcinoma. Lancet 2013;381:400-12.

2. Jemal A, Bray F, Center MM, Ferlay J, Ward E, Forman D Global cancer statistics. CA Cancer J Clin 2011;61:69-90.

3. Arnold M, Soerjomataram I, Ferlay J, Forman D. Global incidence of oesophageal cancer by histological subtype in 2012. Gut 2015;64:381-7.

4. Baan R, Straif K, Grosse Y, Secretan B, El Ghissassi F, Bouvard V, Altieri A, Cogliano V; WHO International Agency for research on Cancer Monograph Working Group. Carcinogenicity of alcohol beverages. Lancet Oncol 2007;8:292-3.

5. The International Agency for Research on Cancer. Tobacco Smoke and Involuntary Smoking. Lyone: IARC; 2004. p. $1179-87$.

6. Morita M, Saeki H, Mori M, Kuwano H, Sugimachi K. Risk factors for esophageal cancer and the multiple occurrence of carcinoma in the upper aerodigestive tract. Surgery 2002;131:S1-6.

7. Brooks PJ, Enoch MA, Goldman D, Li TK, Yokoyama A. The alcohol flushing response: an unrecognized risk factor for esophageal cancer from alcohol consumption. PLoS Med 2009;6:e50 
8. Yoshida A, Huang IY, Ikawa M. Molecular abnormality of an inactive aldehyde dehydrogenase variant commonly found in Orientals. Proc Natl Acad Sci U S A 1984;81:258-61.

9. Islami F, Boffetta P, Ren JS, Pedoeim L, Khatib D, Kamangar F. High-temperature beverages and foods and esophageal cancer risk--a systematic review. Int $J$ Cancer 2009;125:491-524.

10. Sandler RS, Nyrén O, Ekbom A, Eisen GM, Yuen J, Josefsson S. The risk of esophageal cancer in patients with achalasia. A population-based study. JAMA 1995;274:1359-62.

11. Contini S, Scarpignato C. Caustic injury of the upper gastrointestinal tract: a comprehensive review. World J Gastroenterol 2013;19:3918-30.

12. Hardefeldt HA, Cox MR, Eslick GD. Association between human papillomavirus (HPV) and oesophageal squamous cell carcinoma: a meta-analysis. Epidemiol Infect 2014;142:1119-37.

13. Rustgi AK, El-Serag HB. Esophageal carcinoma. $N$ Engl J Med 2014;371:2499-509.

14. Rubenstein JH, Taylor JB. Meta-analysis: the association of oesophageal adenocarcinoma with symptoms of gastro-oesophageal reflux. Aliment Pharmacol Ther 2010;32:1222-7.

15. Tramacere I, La Vecchia C, Negri E. Tobacco smoking and esophageal and gastric cardia adenocarcinoma: a meta-analysis. Epidemiology 2011;22:344-9.

16. Tramacere I, Pelucchi C, Bagnardi V, Rota M, Scotti L, Islami F, Corrao G, Boffetta P, LaVecchia C, Negri E. A meta-analysis on alcohol drinking and esophageal and gastric cardia adenocarcinoma risk. Ann Oncol 2012;23:287-97.

17. Kubo A, Corley DA. Body mass index and adenocarcinoma of the esophagus or gastric cardia: a systematic review and meta-analysis. Cancer Epidemiol Biomarkers Prev 2006; $15: 872-8$.

18. O’Doherty MG, Freedman ND, Hollenbeck AR, Schatzkin A, Abnet CC. A prospective cohort study of obesity and risk of oesophageal and gastric adenocarcinoma in the NIH-AARP Diet and Health Study. Gut 2012;61:1261-8.

19. Nieman KM, Romero IL, Van Houten B, Lengyel E. Adipose tissue and adipocytes support tumorigenesis and metastasis. Biochim Biophys Acta 2013;1831:1533-41.

20. Xie FJ, Zhang YP, Zheng QQ, Jin HC, Wang FL, Chen M, Shao L, Zou DH, Yu XM, Mao WM. Helicobacter pylori infection and esophageal cancer risk: an updated meta-analysis. World J Gastroenterol 2013;19:6098-107.

21. Zablotska LB, Chak A, Das A, Neugut AI. Increased risk of squamous cell esophageal cancer after adjuvant radiation therapy for primary breast cancer. Am $J$ Epidemiol 2005;161:330-7.

22. Morton LM, Gilbert ES, Stovall M, van Leeuwen FE, Dores GM, Lynch CF, Hall P, Smith SA, Weathers RE, Storm HH, Hodgson DC, Kleinerman RA, Joensuu H, Johannesen TB, Andersson M, Holowaty EJ, Kaijsar M, Pukkala E, Vaalavirta L, Fossa SD, Landmark F, Travis LB, Lamart S, Simon SL, Fraumeni JF Jr, Aleman BM, Curtis RE. Risk of esophageal cancer following radiotherapy for Hodgkin lymphoma. Haematologica 2014;99:e193-6.

23. Brown LM, Devesa SS, Chow WH. Incidence of adenocarcinoma of the esophagus among white Americans by sex, stage, and age. J Natl Cancer Inst 2008;100:1184-7.

24. Hansson LE, Sparén P, Nyrén O. Increasing incidence of both major histological types of esophageal carcinomas among men in Sweden. Int J Cancer 1993;54:402-7.

25. Corley DA, Kubo A, Zhao W. Abdominal obesity and the risk of esophageal and gastric cardia carcinomas. Cancer Epidemiol Biomarkers Prev 2008;17:352-8.

26. Khushalani N. Cancer of the esophagus and stomach. Mayo Clin Poc 2008;83:712-22.

27. Chandanos E, Lagergren J. The mystery of male dominance in oesophageal cancer and the potential protective role of oestrogen. Eur J Cancer 2009;45:3149-55.

28. Chang-Claude J, Becher H, Blettner M, Qiu S, Yang G, Wahrendorf J. Familial aggregation of oesophageal cancer in a high incidence area in China. Int J Epidemiol 1997;26:1159-65.

29. Verbeek RE, Spittuler LF, Peute A, van Oijen MG, Ten Kate FJ, Vermeijden JR, Oberndorff A, van Baal JW, Siersema PD. Familial clustering of Barrett's esophagus and esophageal adenocarcinoma in a European cohort. Clin Gastroenterol Hepatol 2014;12:1656-63.e1.

30. Sugimachi K, Ohno S, Matsuda H, Mori M, Kuwano H. Lugol-combined endoscopic detection of minute malignant lesions of the thoracic esophagus. Ann Surg 1988;208:179-83.

31. Muto M, Minashi K, Yano T, Saito Y, Oda I, Nonaka S, Omori T, Sugiura H, Goda K, Kaise M, Inoue H, Ishikawa H, Ochiai A, Shimoda T, Watanabe H, Tajiri H, Saito D. Early detection of superficial squamous cell carcinoma in the head and neck region and esophagus by narrow band imaging: a multicenter randomized controlled trial. $J$ Clin Oncol 2010;28:1566-72.

32. Chung CS, Liao LJ, Lo WC, Chou YH, Chang YC, Lin YC, Hsu WF, Shueng PW, Lee TH. Risk factors for second primary neoplasia of esophagus in newly diagnosed head and neck cancer patients: a case-control study. BMC Gastroenterol 2013;13:154.

33. Spechler SJ. Barrett esophagus and risk of esophageal cancer: a clinical review. JAMA 2013;310:627-36.

34. Gaddam S, Singh M, Balasubramanian G, Thota P, Gupta N, Wani S, Gigbee AD, Mathur SC, Horwhat JD, Rastogi A, Young PE, Cash BD, Bansal A, Vargo JJ, Falk GW, Liberman DA, Sampliner RE, Sharma P. Persistence of nondysplastic Barrett's esophagus identifies patients at lower risk for esophageal adenocarcinoma: results from a large multicenter cohort. Gastroenterology 2013;145:548-53.e1.

35. Lin DC, Hao JJ, Nagata Y, Xu L, Shang L, Meng X, Sato Y, Okuno Y, Varela AM, Ding LW, Garg M, Liu LZ, Yang H, Yin D, Shi ZZ, Jiang YY, Gu WY, Gong T, Zhang Y, Xu X, Kalid O, Shacham S, Ogawa S, Wang MR, Koeffler HP. Genomic and molecular characterization of esophageal squamous cell carcinoma. Nat Genet 2014;46:467-73.

36. Dulak AM, Stojanov P, Peng S, Lawrence MS, Fox C, Stewart C, Bandla S, Imamura Y, Schumacher SE, Shefler E, McKenna A, Carter SL, Cibulskis K, Sivachenko A, Saksena G, Voet D, Ramos AH, Auclair D, Thompson K, Sougnez C, Onofrio RC, Guiducci C, Beroukhim R, Zhou Z, Lin L, Lin J, Reddy R, Chang A, Landerenau R, Pennathur A, Ogino S, Luketich JD, Golub TR, Gabriel SB, Lander ES, Beer DG, Godfrey TE, Getz G, Bass AJ. Exome and whole-genome sequencing of esophageal adenocarcinoma identifies recurrent driver events and mutational complexity. Nat Genet 2013;45:478-86.

37. Hollstein M, Sidransky D, Vogelstein B, Harris CC. p53 mutations in human cancers. Science 1991;253:49-53.

38. Samuels Y, Velculescu VE. Oncogenic mutations of PIK3CA in human cancers. Cell Cycle 2004;3:1221-4.

39. Shigaki H, Baba $Y$, Watanabe M, Murata A, Ishimoto $T$, Iwatsuki M, Iwagami S, Nosho K, Baba H. PIK3CA mutation is associated with a favorable prognosis among patients with curatively resected esophageal squamous cell carcinoma. Clin Cancer Res 2013;19:2451-9. 
40. Katoh M, Katoh M. Notch signaling in gastrointestinal tract (review). Int J Oncol 2007;30:247-51.

41. Foulkes WD, Flanders TY, Pollock PM, Hayward NK. The CDKN2A (p16) gene and human cancer. Mol Med 1997;3:5-20.

42. Hata A. TGFbeta signaling and cancer. Exp Cell Res 2001;264:111-6.

43. Wu RC, Wang TL, Shih IeM. The emerging roles of ARID1A in tumor suppression. Cancer Biol Ther 2014;15:655-64.

44. Weaver JM, Ross-Innes CS, Shannon N, Lynch AG, Forshew T, Barbera M, Murtaza M, Ong CA, Lao-Sirieix P, Dunning MJ, Smith L, Smith ML, Anderson CL, Carvalho B, O’Donovan M, Underwood TJ, May AP, Grehan N, Hardwick R, Davies J, Oloumi A, Apariscio S, Caldas C, Eldridge $\mathrm{MD}$, Edwards PA, Rosenfeld N, Tavaré S, Fitzgerald RC, OCCAMS Consortium. Ordering of mutations in preinvasive disease stages of esophageal carcinogenesis. Nat Genet 2014;46:837-43.

45. Rumiato E, Pasello G, Montagna M, Scaini MC, De Salvo GL, Parenti A, Cagol M, Ruol A, Ancona E, Amadori A, Saggioro D. DNA copy number profile discriminates between esophageal adenocarcinoma and squamous cell carcinoma and represents an independent prognostic parameter in esophageal adenocarcinoma. Cancer Lett 2011;310:84-93.

46. Jiang W, Kahn SM, Tomita N, Zhang YJ, Lu SH, Weinstein IB. Amplification and expression of the human cyclin D gene in esophageal cancer. Cancer Res 1992;52:2980-3.

47. Aoki K, Taketo MM. Adenomatous polyposis coli (APC): a multi-functional tumor suppressor gene. $J$ Cell Sci 2007; 120:3327-35.

48. Pekarsky Y, Zanesi N, Palamarchuk A, Huebner K, Croce CM. FHIT: from gene discovery to cancer treatment and prevention. Lancet Oncol 2002;3:748-54.

49. Nelson HH, Wiencke JK, Gunn L, Wain JC, Christiani DC, Kelsey KT. Chromosome 3p14 alterations in lung cancer: Evidence that FHIT exon deletion is a target of tobacco carcinogens and asbestos. Cancer Res 1998;58:1804-7.

50. Mori M, Mimori K, Shiraishi T, Alder H, Inoue H, Tanaka Y, Sugimachi K, Huebner K, Croce CM. Altered expression of Fhit in carcinoma and precarcinomatous lesions of the esophagus. Cancer Res 2000;60:1177-82.

51. Hechtman JF, Polydorides AD. HER2/neu gene amplification and protein overexpression in gastric and gastroesophageal junction adenocarcinoma: A review of histopathology, diagnostic testing, and clinical implications. Arch Pathol Lab Med 2012;136:691-7.

52. Bang YJ, Van Cutsem E, Feyereislova A, Chung HC, Shen L, Sawaki A, Lordick F, Ohtsu A, Omuro Y, Satoh T, Aprile G, Kulikov E, Hill J, Lehle M, Ruschoff J, Kang YK, ToGA Trial Investigators. Trastuzumab in combination with chemotherapy versus chemotherapy alone for treatment of HER2-positive advanced gastric or gastro-oesophageal junction cancer (ToGA): A phase 3, open-label, randomised controlled trial. Lancet 2010;376:687-97.

53. Bandla S, Peters JH, Ruff D, Chen SM, Li CY, Song K, Thoms K, Litle VR, Watson T, Chapurin N, Lada M, Pennathur A, Luketich JD, Peterson D, Dulak A, Lin L, Bass A, Beer DG, Godfrey TE, Zhou Z. Comparison of cancer-associated genetic abnormalities in columnar-lined esophagus tissues with and without goblet cells. Ann Surg 2014;260:72-80.

54. Baba Y, Watanabe M, Baba H. Review of the alterations in DNA methylation in esophageal squamous cell carcinoma. Surg Today 2013;43:1355-64.

55. Cavallaro U, Christofori G. Cell adhesion and signalling by cadherins and Ig-CAMs in cancer. Nat Rev Cancer 2004;4:118-32.

56. Ha PK, Califano JA. Promotor methylation and inactivation of tumor-suppressor genes in oral squamous-cell carcinoma. Lancet Oncol 2006; 7:77-82.

57. Donninger H, Vos MD, Clark GJ. The RASSF1A tumor suppressor. J Cell Sci 2007;120:3163-72.

58. Gerson SL. MGMT: Its role in cancer aetiology and cancer therapeutics. Nat Rev Cancer 2004;4:296-307.

59. Vasavi M, Kiran V, Ravishankar B, Prabhakar B, Ahuja YR, Hasan Q. Microsatellite instability analysis and its correlation with hMLH1 repair gene hypermethylation status in esophageal pathologies including cancers. Cancer Biomark 2010;7:1-10.

60. Clément G, Braunschweig R, Pasquier N, Bosman FT, Benhattar J. Methylation of APC, TIMP3, and TERT: A new predictive marker to distinguish Barrett's oesophagus patients at risk for malignant transformation. J Pathol 2006;208:100-7.

61. Schildhaus HU, Kröckel I, Lippert H, Malfertheiner P, Roessner A, Schneider-Stock R. Promoter hypermethylation of p16INK4a, E-cadherin, O6-MGMT, DAPK and FHIT in adenocarcinomas of the esophagus, esophagogastric junction and proximal stomach. Int J Oncol 2005;26:1493-500.

62. Jin Z, Hamilton JP, Yang J, Mori Y, Olaru A, Sato F, Ito T, Kan T, Cheng Y, Paun B, David S, Beer DG, Agarwal R, Abraham JM, Meltzer SJ. Hypermethylation of the AKAP12 promoter is a biomarker of Barrett's-associated esophageal neoplastic progression. Cancer Epidemiol Biomarkers Prev 2008;17:111-7.

63. Tischoff I, Hengge UR, Vieth M, Ell C, Stolte M, Weber A, Schmidt WE, Tannapfel A. Methylation of SOCS-3 and SOCS-1 in the carcinogenesis of Barrett's adenocarcinoma. Gut 2007;56:1047-53.

64. Rettori MM, de Carvalho AC, Longo AL, de Oliveira CZ, Kowalski LP, Carvalho AL, Vettore AL. TIMP3 and CCNA1 hypermethylation in HNSCC is associated with an increased incidence of second primary tumors. J Transl Med 2013;11:316.

65. Kuester D, Dar AA, Moskaluk CC, Krueger S, Meyer F, Hartig R, Stolte M, Malfertheiner P, Lippert H, Roessner A, El-Rifai W, Schneider-Stock R. Early involvement of death-associated protein kinase promoter hypermethylation in the carcinogenesis of Barrett's esophageal adenocarcinoma and its association with clinical progression. Neoplasia 2007;9:236-45.

66. Valentino L, Pierre J. JAK/STAT signal transduction: regulators and implication in hematological malignancies. Biochem Pharmacol 2006;71:713-21.

67. Iwagami S, Baba Y, Watanabe M, Shigaki H, Miyake K, Ishimoto T, Iwatsuki M, Sakamaki K, Ohashi Y, Baba H. LINE-1 hypomethylation is associated with a poor prognosis among patients with curatively resected esophageal squamous cell carcinoma. Ann Surg 2013;257:449-55.

68. Xu E, Gu J, Hawk ET, Wang KK, Lai M, Huang M, Ajani J, Wu X. Genome-wide methylation analysis shows similar patterns in Barrett's esophagus and esophageal adenocarcinoma. Carcinogenesis 2013;34:2750-6.

69. Dawson MA, Kouzarides T. Cancer epigenetics: from mechanism to therapy. Cell 2012;150:12-27.

70. Bojang $\mathrm{P} \mathrm{Jr}$, Ramos KS. The promise and failures of epigenetic therapies for cancer treatment. Cancer Treat Rev 2014;40:153-69.

71. Langer R, Mutze K, Becker K, Feith M, Ott K, Höfler H, Keller G. Expression of class I histone deacetylases (HDAC1 and HDAC2) in oesophageal adenocarcinomas: an immunohistochemical study. J Clin Pathol 2010;63:994-8. 
72. Croce CM, Calin GA. miRNAs, cancer, and stem cell division. Cell 2005;122:6-7.

73. Hiyoshi Y, Kamohara H, Karashima R, Sato N, Imamura Y, Nagai Y, Yoshida N, Toyama E, Hayashi N, Watanabe M, Baba H. MicroRNA-21 regulates the proliferation and invasion in esophageal squamous cell carcinoma. Clin Cancer Res 2009;15:1915-22.

74. Mori $\mathrm{Y}$, Ishiguro H, Kuwabara Y, Kimura M, Mitsui A, Ogawa R, Katada T, Harata K, Tanaka T, Shiozaki M, Fujii Y. MicroRNA-21 induces cell proliferation and invasion in esophageal squamous cell carcinoma. Mol Med Rep 2009;2:235-9.

75. Wijnhoven BP, Hussey DJ, Watson DI, Tsykin A, Smith CM, Michael MZ, South Australian Oesophageal Research Group. MicroRNA profiling of Barrett's oesophagus and oesophageal adenocarcinoma. Br J Surg 2010;97:853-61.

76. Ma WJ, Lv GD, Tuersun A, Liu Q, Liu H, Zheng ST, Huang CG, Feng JG, Wang X, Lin RY, Sheyhidin I, $\mathrm{Lu} \mathrm{XM.} \mathrm{Role} \mathrm{of} \mathrm{microRNA-21} \mathrm{and} \mathrm{effect} \mathrm{on} \mathrm{PTEN} \mathrm{in}$ Kazakh's esophageal squamous cell carcinoma. Mol Biol Rep 2011;38:3253-60.

77. Kurashige J, Kamohara H, Watanabe M, Tanaka Y, Kinoshita K, Saito S, Hiyoshi Y, Iwatsuki M, Baba Y, Baba H. Serum microRNA-21 is a novel biomarker in patients with esophageal squamous cell carcinoma. J Surg Oncol 2012;106:188-92.

78. Tanaka Y, Kamohara H, Kinoshita K, Kurashige J, Ishimoto T, Iwatsuki M, Watanabe M, Baba H. Clinical impact of serum exosomal microRNA-21 as a clinical biomarker in human esophageal squamous cell carcinoma. Cancer 2013;119:1159-67.

79. Kinoshita T, Hanazawa T, Nohata N, Okamoto Y, Seki N. The functional significance of microRNA-375 in human squamous cell carcinoma: Aberrant expression and effects on cancer pathways. J Hum Genet 2012;57:556-63.

80. Mathé EA, Nguyen GH, Bowman ED, Zhao Y, Budhu A,
Schetter AJ, Braun R, Reimers M, Kumamoto K, Hughes D, Altorki NK, Casson AG, Liu CG, Wang XW, Yanaihara N, Hagiwara N, Dannenberg AJ, Miyashita M, Croce CM, Harris CC. MicroRNA expression in squamous cell carcinoma and adenocarcinoma of the esophagus: associations with survival. Clin Cancer Res 2009;15:6192-200.

81. Feber A, Xi L, Luketich JD, Pennathur A, Landreneau RJ, Wu M, Wu M, Swanson SJ, Godfrey TE, Litle VR. MicroRNA expression profiles of esophageal cancer. $J$ Thorac Cardiovasc Surg 2008;135:255-60.

82. Matsushima $\mathrm{K}$, Isomoto $\mathrm{H}$, Yamaguchi $\mathrm{N}$, Inoue $\mathrm{N}$, Machida H, Nakayama T, Hayashi T, Kunizaki M, Hidaka S, Nagayasu T, Nakashima M, Ujifuku K, Mitsutake N, Ohtsuru A, Yamashita S, Korpal M, Kang Y, Gregory PA, Goodall GJ, Kohno S, Nakao K. MiRNA-205 modulates cellular invasion and migration via regulating zinc finger E-box binding homeobox 2 expression in esophageal squamous cell carcinoma cells. $J$ Transl Med 2011;9:30.

83. Kurashige J, Watanabe M, Iwatsuki M, Kinoshita K, Saito S, Hiyoshi Y, Kamohara H, Baba Y, Mimori K, Baba H. Overexpression of microRNA-223 regulates the ubiquitin ligase FBXW7 in oesophageal squamous cell carcinoma. Br J Cancer 2012;106:182-8.

84. Matsuzaki J, Suzuki H. MicroRNAs in Barrett's esophagus: future prospects. Front Genet 2014;5:69.

85. Revilla-Nuin B, Parrilla P, Lozano JJ, de Haro LF, Ortiz A, Martínez C, Munitiz V, de Angulo DR, Bermejo J, Molina J, Cayuele ML, Yélamos J. Predictive value of MicroRNAs in the progression of barrett esophagus to adenocarcinoma in a long-term follow-up study. Ann Surg 2013;257:886-93.

How to cite this article: Watanabe M. Risk factors and molecular mechanisms of esophageal cancer: differences between the histologic subtype. J Cancer Metastasis Treat 2015;1:1-7.

Received: 08-02-2015; Accepted: 03-03-2015.

Source of Support: Nil, Conflict of Interest: None declared. 